\title{
Eco-Friendly Management of Powdery Mildew of Mango through Biocontrol Agents
}

\author{
Lovepreet Kaur $^{1}$, Bhupesh Gupta ${ }^{1}$, I.M. Sharma ${ }^{1}$ and A.K. Joshi ${ }^{2 *}$ \\ ${ }^{1}$ Department of Plant Pathology, Dr YS Parmar University of Horticulture and Forestry, \\ Nauni, Solan 173230 (HP), India \\ ${ }^{2}$ Regional Horticultural Research and Training Station, Dhaulakuan, \\ Sirmour - 173001 (HP), India \\ *Corresponding author
}

\section{A B S T R A C T}

Powdery mildew caused by Oidium mangiferae is a serious disease of mango inflicting considerable quantitative as well as qualitative losses. Though the disease can be

\section{Keywords}

Biocontrol agents,

Mango, powdery mildew, Oidium mangiferae

Article Info

Accepted:

04 September 2018

Available Online:

10 October 2018 successfully managed by agro-chemicals but due to non-eco-friendly nature, high cost and other side effects of chemical control measures, search for eco-friendly, sustainable, low cost strategies becomes inevitable. In the present study, six biocontrol agents (BCAs) viz., Trichoderma viride, Bacillus subtilis, Pseudomonas fluorescens, Verticillium lecanii, Ampelomyces quisqualis, Trichoderma harzianum were evaluated for their bio-efficacy against powdery mildew of mango at three concentration levels $(0.4,0.6$ and $0.8 \%)$ under field conditions at RHR\&TS, Dhaulakuan during 2014. All the biocontrol agents were then further tested at 0.8 per cent concentration at RHR\&TS, Dhaulakuan and Jachh during 2015. During 2014, both Bacillus subtilis (Mildown) and Ampelomyces quisqualis (Milgo) @ 0.8 per cent exhibited higher degree of disease control to the tune of 97.34 per cent and 92.95 per cent, respectively. Pseudomonas fluorescens at all the three concentrations $(0.4$, 0.6 and $0.8 \%$ ) was found to be the least effective. While testing at two locations Bacillus subtilis and Ampelomyces quisqualis have shown higher degree of per cent disease control i.e. 97.67 per cent and 93.99 per cent, respectively.

\section{Introduction}

Mango (Mangifera indica L.) is one of the most celebrated tropical fruits, being cultivated over an area of 2262770 ha producing $19686930 \mathrm{Mt}$ with a productivity of 8.71 MT/ha (NHB, 2017). In Himachal Pradesh, mango is being cultivated over 41,520 ha with annual production of 47400 MT with a productivity of $1.14 \mathrm{MT} / \mathrm{ha}$ (NHB, 2017). Different factors are responsible for low productivity of mango, prominently diseases, especially powdery mildew plays an important role after the infestation of insects. Powdery mildew caused by Oidium mangiferae Berthet is widely distributed and can infect leaves, bloom clusters and young fruits resulting in severe fruit drop and under epidemic conditions it may result in complete failure of the crop (Mishra, 2001). Flowering stage thus appears to be the most critical stage for infection. In recent years, the awareness 
among the scientific and farming communities on ill effects of chemical pesticides has led to evolve a sound and viable plant protection alternatives rather than sole dependence on chemical pesticides, though these pesticides provide excellent control of the target pest but the remittance of environmental pollution cannot be ignored. Biological control is safer and can become an integral component of the IPM which involves the use of any living organism and it's by product to contain other living organism which is a pest. Biological control has emerged as an eco-friendly crop protection approach to replace or supplement the use of chemical pesticides. Over the past three decades, research has repeatedly demonstrated the effectiveness of number of microorganisms that can act as natural antagonists to plant pathogens (Cook, 2000).

Powdery mildew fungi are prime targets for biocontrol agents because of their superficial growth (Belanger et al., 1997). This had attracted many researchers to conduct intensive investigations in order to find antagonists that can provide acceptable levels of disease control. Although consistency had been the major concern in controlling powdery mildew with the antagonists, however most of the BCAs have produced promising results in suppressing powdery mildew.

\section{Materials and Methods}

Four biocontrol agents (BCAs) namely Mildown (Bacillus subtilis), Bactavipe (Pseudomonas fluorescens), Varunastra (Verticillium lecanii), Milgo (Ampelomyces quisqualis), formulations procured from "International Panaacea Limited, New Delhi" manufactures and Tricho-vir (Trichoderma viride), Bioherz (Trichoderma harzianum) were obtained from "the department of Plant Pathology, UHF, Nauni". These were evaluated at three concentrations levels $(0.4$, 0.6 and $0.8 \%$ ) under field conditions for their bio-efficacy against powdery mildew on mango cv. "Dashehri" under natural epiphytotic conditions at RHR\&TS, Dhaulakuan in 2014. The concentration of 0.8 percent, which was found to be most effective in 2014 at RHR\&TS, Dhaulakuan was used to evaluate the biocontrol agents at RHRT\&Ss, Dhaulakuan and Jachh during 2015. Each biocontrol agent was sprayed thrice at an interval of 15 days starting with the emergence of panicles. The tree sprayed with water served as control. The experiment was laid out in Randomized Block Design (RBD) and each treatment was replicated thrice. The data on disease severity was recorded after fifteen days of last spray and the per cent disease index by following a disease rating scale of 0 to 4 as described by Datar (1992), where:

$0=$ Inflorescence free from infection

$1=$ Less than 25 per cent of the inflorescence covered by powdery mildew

$2=26-50$ per cent of the inflorescence covered by powdery mildew

$3=51-75$ per cent of the inflorescence covered by powdery mildew

$4=$ More than 75 per cent of the inflorescence covered by powdery mildew

Sum of all the disease ratings Disease index $(\%)=$

Total number of samples observed $\mathrm{x}$ Maximum disease grade

\section{Results and Discussion}

The perusal of the data (Table 1) revealed that all the biocontrol agents formulations were effective in lowering the disease severity and disease control increased with the increase in concentration of biological control agents. 
Three applications of Bacillus subtilis formulation during 2014 provided maximum percent disease control of 90.57 per cent. It was followed by Ampelomyces quisqualis with 81.32 percent and Verticillium lecanii (63.58\%), Trichoderma harzianum (59.81\%) and $T$. viridae (41.74\%). While comparing concentrations irrespective of treatment (BCAs), 0.8 percent was found to be the most effective.

Comparison of the interactions of concentrations and biological control agents revealed that maximum percent disease control (97.34\%) was achieved with Bacillus subtilis at 0.8 percent concentration. It was followed by Ampelomyces quisqualis at 0.8 percent $(92.95 \%)$ and Bacillus subtilis at 0.6 percent (91.52\%). Pseudomonas fluorescens at all the three concentrations $(0.4,0.6$ and $0.8 \%)$ was found to be the least effective.

Since concentration@0.8 percent for all the treatments was found to be most effective, therefore the experiment during 2015 was laid with concentration@0.8\% for all the seven biocontrol agents at two locations i.e. RHR\&TS, Dhaulakuan and Jachh and data so obtained was presented in Table 2. Data presented in Table 2 revealed that disease was more severe at Jachh than at Dhaulakuan. Mean of two locations revealed that maximum percent disease control (97.67\%) was achieved with Bacillus subtilis and was followed by Ampelomyces quisqualis (93.99\%). Pseudomonas fluorescens (56.34\%) and Trichoderma viride $(60.29 \%)$ were found to be least effective treatments.

Table.1 Efficacy of biocontrol agents against powdery mildew on mango under field conditions at RHR\&TS Dhaulakuan during the year 2014

\begin{tabular}{|c|c|c|c|c|c|c|c|c|}
\hline \multirow{3}{*}{ 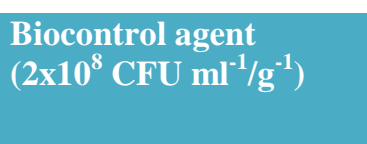 } & \multicolumn{4}{|c|}{ Disease index (\%) } & \multicolumn{4}{|c|}{ Disease control (\%) } \\
\hline & \multicolumn{3}{|c|}{ Conc. (\%) } & \multirow{2}{*}{$\begin{array}{l}\text { Mean } \\
\text { (BCA) }\end{array}$} & \multicolumn{3}{|c|}{ Conc. (\%) } & \multirow{2}{*}{$\begin{array}{r}\text { Mean } \\
\text { (BCA) }\end{array}$} \\
\hline & 0.4 & 0.6 & 0.8 & & 0.4 & 0.6 & 0.8 & \\
\hline $\begin{array}{l}\text { Bacillus subtilis } \\
\text { (Mildown) }\end{array}$ & $\begin{array}{c}10.29 \\
(18.70)\end{array}$ & $\begin{array}{c}5.10 \\
(13.05)\end{array}$ & $\begin{array}{c}1.60 \\
(7.26)\end{array}$ & $\begin{array}{c}5.66 \\
(13.00)\end{array}$ & $\begin{array}{l}82.85 \\
(65.64)\end{array}$ & $\begin{array}{c}91.52 \\
(73.12)\end{array}$ & $\begin{array}{c}97.34 \\
(80.87)\end{array}$ & $\begin{array}{c}90.57 \\
(73.21)\end{array}$ \\
\hline $\begin{array}{l}\text { Trichoderma harzianum } \\
\text { (Bioherz) }\end{array}$ & $\begin{array}{c}30.27 \\
(33.36)\end{array}$ & $\begin{array}{l}23.20 \\
(28.75)\end{array}$ & $\begin{array}{l}19.28 \\
(26.08)\end{array}$ & $\begin{array}{c}24.29 \\
(29.43)\end{array}$ & $\begin{array}{r}49.88 \\
(45.00)\end{array}$ & $\begin{array}{c}61.73 \\
(51.35)\end{array}$ & $\begin{array}{c}67.81 \\
(55.56)\end{array}$ & $\begin{array}{c}59.81 \\
(50.64)\end{array}$ \\
\hline $\begin{array}{l}\text { Verticillum lacanii } \\
\text { (Varunastra) }\end{array}$ & $\begin{array}{c}31.20 \\
(33.94)\end{array}$ & $\begin{array}{l}22.87 \\
(28.54)\end{array}$ & $\begin{array}{c}11.34 \\
(19.56)\end{array}$ & $\begin{array}{c}21.80 \\
(27.35)\end{array}$ & $\begin{array}{c}48.09 \\
(44.27)\end{array}$ & $\begin{array}{c}61.94 \\
(52.07)\end{array}$ & $\begin{array}{c}80.70 \\
(64.40)\end{array}$ & $\begin{array}{c}63.58 \\
(53.58)\end{array}$ \\
\hline $\begin{array}{l}\text { Ampelomyces quisqualis } \\
\text { (Milgo) }\end{array}$ & $\begin{array}{l}18.80 \\
(25.68)\end{array}$ & $\begin{array}{c}10.90 \\
(19.22)\end{array}$ & $\begin{array}{c}4.26 \\
(11.66)\end{array}$ & $\begin{array}{c}11.32 \\
(18.85)\end{array}$ & $\begin{array}{c}69.02 \\
(56.17)\end{array}$ & $\begin{array}{c}82.00 \\
(64.89)\end{array}$ & $\begin{array}{c}92.95 \\
(74.60)\end{array}$ & $\begin{array}{c}81.32 \\
(65.22)\end{array}$ \\
\hline $\begin{array}{l}\text { Trichoderma viride } \\
\text { (Tricho-vir) }\end{array}$ & $\begin{array}{c}40.23 \\
(39.33)\end{array}$ & $\begin{array}{c}34.65 \\
(36.06)\end{array}$ & $\begin{array}{c}30.21 \\
(33.34)\end{array}$ & $\begin{array}{c}35.03 \\
(36.25)\end{array}$ & $\begin{array}{r}33.00 \\
(35.06)\end{array}$ & $\begin{array}{c}42.00 \\
(40.39)\end{array}$ & $\begin{array}{r}50.23 \\
(45.13)\end{array}$ & $\begin{array}{r}41.74 \\
(40.19)\end{array}$ \\
\hline $\begin{array}{l}\text { Pseudomonas } \\
\text { fluorescens (Bactavipe) }\end{array}$ & $\begin{array}{c}42.33 \\
(40.56)\end{array}$ & $\begin{array}{c}39.16 \\
(38.70)\end{array}$ & $\begin{array}{c}34.07 \\
(35.68)\end{array}$ & $\begin{array}{c}38.52 \\
(38.31)\end{array}$ & $\begin{array}{r}30.79 \\
(33.70)\end{array}$ & $\begin{array}{c}35.48 \\
(36.55)\end{array}$ & $\begin{array}{c}43.69 \\
(41.37)\end{array}$ & $\begin{array}{c}36.65 \\
(37.21)\end{array}$ \\
\hline Control & $\begin{array}{c}60.78 \\
(51.22)\end{array}$ & $\begin{array}{c}60.78 \\
(51.22)\end{array}$ & $\begin{array}{c}60.78 \\
(51.22)\end{array}$ & $\begin{array}{c}60.78 \\
(51.22)\end{array}$ & - & - & - & \\
\hline Mean (Conc.) & $\begin{array}{c}28.85 \\
(34.59)\end{array}$ & $\begin{array}{c}22.65 \\
(27.42)\end{array}$ & $\begin{array}{c}16.81 \\
(22.34)\end{array}$ & & $\begin{array}{c}52.42 \\
(46.64)\end{array}$ & $\begin{array}{c}62.38 \\
(53.06)\end{array}$ & $\begin{array}{c}72.26 \\
(60.32)\end{array}$ & \\
\hline \multicolumn{9}{|l|}{$\mathrm{CD}_{0.05}$} \\
\hline $\mathbf{B C A}(\mathbf{A})$ & 2.32 & & & & 23.53 & & & \\
\hline Conc.(B) & 1.52 & & & & 2.31 & & & \\
\hline Interaction (A X B) & 4.08 & & & & 6.11 & & & \\
\hline
\end{tabular}

Figures in the parentheses are arc sine transformed values 
Table.2 Efficacy of biocontrol agents against powdery mildew on mango under field conditions at RHR\&TS Dhaulakuan and Jachh during the year 2015

\begin{tabular}{|c|c|c|c|c|c|c|}
\hline \multirow{2}{*}{ 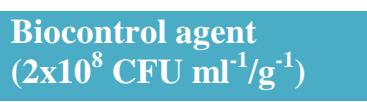 } & \multicolumn{3}{|c|}{ Disease index (\%) } & \multicolumn{3}{|c|}{ Disease control (\%) } \\
\hline & Dhaulakuan & Jachh & Mean & Dhaulakuan & Jachh & Mean \\
\hline $\begin{array}{l}\text { Bacillus subtilis } \\
\text { (Mildown) }\end{array}$ & $\begin{array}{c}1.67 \\
(7.38)\end{array}$ & $\begin{array}{c}1.50 \\
(5.67)\end{array}$ & $\begin{array}{c}1.58 \\
(6.99)\end{array}$ & $\begin{array}{l}97.36 \\
(80.67)\end{array}$ & $\begin{array}{c}97.99 \\
(83.39)\end{array}$ & $\begin{array}{c}97.67 \\
(\mathbf{8 1 . 4 5})\end{array}$ \\
\hline $\begin{array}{l}\text { Trichoderma harzianum } \\
\text { (Bioherz) }\end{array}$ & $\begin{array}{l}20.50 \\
(26.88)\end{array}$ & $\begin{array}{l}21.67 \\
(27.68)\end{array}$ & $\begin{array}{c}21.08 \\
(27.39)\end{array}$ & $\begin{array}{c}67.80 \\
(55.43)\end{array}$ & $\begin{array}{c}71.35 \\
(57.68)\end{array}$ & $\begin{array}{c}69.57 \\
(56.51)\end{array}$ \\
\hline $\begin{array}{l}\text { Verticillum lacanii } \\
\text { (Varunastra) }\end{array}$ & $\begin{array}{c}11.67 \\
(19.84)\end{array}$ & $\begin{array}{c}10.83 \\
(19.23)\end{array}$ & $\begin{array}{c}11.25 \\
(19.48)\end{array}$ & $\begin{array}{l}81.85 \\
(64.84)\end{array}$ & $\begin{array}{l}85.86 \\
(67.95)\end{array}$ & $\begin{array}{l}83.85 \\
(66.36)\end{array}$ \\
\hline $\begin{array}{l}\text { Ampelomyces quisqualis } \\
\text { (Milgo) }\end{array}$ & $\begin{array}{c}4.47 \\
(11.98)\end{array}$ & $\begin{array}{c}3.83 \\
(11.10)\end{array}$ & $\begin{array}{c}4.15 \\
(11.68)\end{array}$ & $\begin{array}{l}92.97 \\
(74.85)\end{array}$ & $\begin{array}{c}95.02 \\
(77.25)\end{array}$ & $\begin{array}{r}93.99 \\
(75.83)\end{array}$ \\
\hline $\begin{array}{l}\text { Trichoderma viride } \\
\text { (Tricho-vir) }\end{array}$ & $\begin{array}{c}31.17 \\
(33.89)\end{array}$ & $\begin{array}{l}23.10 \\
(28.64)\end{array}$ & $\begin{array}{c}27.13 \\
(31.38)\end{array}$ & $\begin{array}{l}51.08 \\
(45.60)\end{array}$ & $\begin{array}{c}69.50 \\
(56.55)\end{array}$ & $\begin{array}{r}60.29 \\
(50.92)\end{array}$ \\
\hline $\begin{array}{l}\text { Pseudomonas } \\
\text { fluorescens (Bactavipe) }\end{array}$ & $\begin{array}{c}32.16 \\
(34.53)\end{array}$ & $\begin{array}{l}24.80 \\
(29.82)\end{array}$ & $\begin{array}{c}28.48 \\
(32.24)\end{array}$ & $\begin{array}{c}49.45 \\
(44.65)\end{array}$ & $\begin{array}{c}67.21 \\
(55.10)\end{array}$ & $\begin{array}{r}56.34 \\
(49.79)\end{array}$ \\
\hline Control & $\begin{array}{c}63.67 \\
(52.93)\end{array}$ & $\begin{array}{c}76.07 \\
(60.74)\end{array}$ & $\begin{array}{c}69.87 \\
(56.72)\end{array}$ & & & \\
\hline $\mathrm{CD}_{0.05}$ & 3.09 & 5.39 & 3.17 & 3.55 & 5.83 & 3.36 \\
\hline
\end{tabular}

Figures in the parentheses are arc sine transformed values

Antagonism between micro-organisms is a common phenomenon. Plant pathogenic fungi and bacteria can also be affected by fungal and bacterial antagonists (Cook and Baker, 1983). Among different biocontrol agents formulations evaluated under field conditions, Bacillus subtilis (Mildown) showed maximum control followed by Ampelomyces quisqualis (Milgo) both at 0.8 per cent. Sztejnberg et al., (1989) and Srivastava (2003) observed that formulation of Ampelomyces quisqualis is capable of parasitizing $O$. mangiferae and lowered the severity of powdery mildew on mango trees with increasing the fruit yield. The former also established that $A$. quisqualis was compatible with many fungicides currently used to control the powdery mildews. Kiss et al., (2004) explained that reduction of powdery mildew by the use of bioagnts on many vegetable and horticultural crops is mainly due to their hyperparasitism on powdery mildew pathogen. The different mechanisms implicated in antagonism of powdery mildew fungus included mycoparasitism, competition and induced resistance. Nofal and Haggag (2006) reported that in vitro application of biocontrol agents such as Verticillium lecanii, Bacillus subtilis and Tilletiopsis minor to leaf disks before inoculation with $O$. mangiferae markedly decreased conidial germination and leaf infection.

Among six biocontrol agents evaluated by giving three sprays (starting from two weeks after the panicle emergence) at 15days interval against powdery in mango, two antagonists, namely Bacillus subtilis and Ampelomyces quisqualis @0.8 per cent exhibited higher degree of disease control to the tune of 97.67 and 93.99 per cent, respectively, when tested over two diverse locations. Thus, an eco-friendly spray schedule can help the mango growers in managing the disease.

\section{References}

Belanger R B, Dik A J and Menzies J M. 1997. Powdery mildew: Recent advances toward integrated control. In: Plant microbe Interactions and Biological Control (eds. Boland G J and 
Kuykendall L D). Marcel Dekker, Inc., New York. 89-109

Cook RJ. 2000. Advances in plant health management in the $20^{\text {th }}$ century. Annual review of Phytophatology. 38: 95-116

Cook, RJ and Baker, KF. 1983. The nature and practice of biocontrol of plant pathogens. The American Phytopathological Society, St. Paul, USA.

Datar V.1992. Investigation of powdery mildew of mango caused by Mangiferae Berthet. IV International mango symposium. Miami beach, Florida. U.S.A. Univ. of Florida IFAS Tropical research and education center and international society for Hort. Science. 2

Kiss L, Russell J C, Szentivanyi Xu O and Jeffries X P. 2004. Biology and biocontrol potential of Ampelomyces mycoparsites, natural antagonistis of powdery mildew fungus. Bio. Sci. Tech.14: 635-646

Mishra, AK. 2001. Powdery mildew-A serious disease of mango. J. Appl. Hort. 3:63-68.

NHB. 2017. www.nhb.gov.in

Nofal M A and Haggag W M. 2006. Integrated management of powdery mildew of mango in Egypt. Crop Prot. 480-486

Srivastava R P. 2003. In: Mango Cultivation. International Book Distribution Co., Lucknow, India. p. 8

Sztejnberg A, Galper S, Mazar, Shlomit and Lisker N. 1989. Ampelomyces quisqualis for biological and integrated control of powdery mildews in Israel. $J$. Phytopatho. 124: 285-295

\section{How to cite this article:}

Lovepreet Kaur, Bhupesh Gupta, I.M. Sharma and Joshi, A.K. 2018. Eco-Friendly Management of Powdery Mildew of Mango through Biocontrol Agents. Int.J.Curr.Microbiol.App.Sci. 7(10): 392-396. doi: https://doi.org/10.20546/ijcmas.2018.710.042 